\title{
STUDI EKSPERIMENTAL PENGARUH DINDING BATA TERHADAP KETAHANAN KOLOM STRUKTUR PORTAL SEDERHANA
}

\author{
Ulya Saputra $^{1}$, Harry Syafriandi Eka Putra ${ }^{2}$, Jafril Tanjung ${ }^{3}$, dan Rendy Thamrin ${ }^{4}$
}

\begin{abstract}
ABSTRAK
Indonesia merupakan daerah rawan gempa. Berdasarkan fakta yang dilihat, setelah terjadinya gempa banyak bengunan yang rusak. Komponen yang vital adalah dinding bata. Berdasarkan gempa Padang 2009 memperlihatkan bahwa bangunan bertingkat yang memiliki pasangan dinding bata yang lebih banyak pada lantai dasar dapat bertahan terhadap beban gempa dari pada yang tanpa pakai dinding bata. Berdasarkan SNI 03-2847-2002 dinding bata hanya difungsikan sebagai komponen non struktural yang hanya memberikan beban terhadap struktur. Sedangkan interaksi dinding bata dengan portal yang mengelilinginya serta sumbangan terhadap kekuatan dan kekakuan struktur seringkali diabaikan. Padahal apabila struktur dengan dinding bata tersebut diberi beban gempa yang cukup kuat, maka dinding bata tersebut akan cendrung berinteraksi dengan portal yang mengelilinginya. Berdasarkan investigasi tersebut maka dilakukanlah penelitian yang bertujuan untuk mengetahui seberapa besar konstribusi dari dinding bata terhadap ketahanan struktur beton sederhana saat diberikan beban lateral yaitu representasi dari beban gempa. Penelitian dilakukan dengan lima jenis benda uji yaitu struktur portal sederhana tanpa dinding bata, struktur portal sederhana dengan dinding bata tanpa plesteran, dan struktur portal sederhana dengan dinding bata dengan plesteran. Bata yang digunakan adalah bata normal yang ada dipasaran dan bata skala.Penelitian dilakukan secara eksperimental dan numerik.Penelitian secara numerik dilakukan dengan menggunakan bantuan software ATENA 2D V.4.2 Demo.Hasil pengujian menunjukakan bahwa dinding bata mempunyai konstribusi terhadap struktur bangunan. Hal ini ditunjukkan dengan meningkatnya kapasitas dan kekakuan struktur beton bertulang.
\end{abstract}

Kata kunci : Dinding Bata, Ketahanan Struktur Beton Bertulang, Beban Lateral

\section{PENDAHULUAN}

Indonesia memiliki resiko tinggi akan terjadinya gempa. Kejadian gempa dapat dilihat sepanjang tahun 2004 sampai 2009. Setiap tahun terjadi gempa diberbagai daerah di Indonesia baik dalam skala besar maupun kecil, bahkan beberapa gempa besar menimbulkan kerusakan yang sangat besar bahkan korban jiwa.(Redha Leksono,2014)

Fakta yang bisa dilihat dari pasca gempa adalah banyak bangunan rusak dan roboh. Berdasarkan gempa Padang 2009 memperlihatkan bahwa bangunan bertingkat yang memiliki pasangan dinding bata yang lebih banyak pada lantai dasar dapat bertahan terhadap beban gempa dari pada yang tanpa pakai dinding bata.Penelitian yang dilakukan sebelumnya oleh Maidiawati dan Sanada Y (2011) menunjukkan bahwa dinding bata berperan dalam ketahanan struktur bangunan akibat

\footnotetext{
${ }^{I}$ Mahasiswa Pascasarjana Jurusan Teknik Sipil Fakultas Teknik Universitas Andalas, ulyasaputra@ymail.com

${ }^{2}$ Mahasiswa Pascasarjana Jurusan Teknik Sipil Fakultas Teknik Universitas Andalas, yadi_050@yahoo.com

${ }^{3}$ Staf Pengajar Jurusan Teknik Sipil Fakultas Teknik Universitas Andalas, jafriltanjung@ft.unand.ac.id

${ }^{4}$ Staf Pengajar Jurusan Teknik Sipil Fakultas Teknik Universitas Andalas, rendy@ft.unand.ac.id
} 
beban gempa. Hal ini dibuktikan dengan bangunan yang menggunakan dinding bata lebih bisa bertahan terhadap beban gempa dibandingkan dengan struktur bangunan tanpa dinding bata. Dari sini dapat diketahui bahwa dinding bata memiliki nilai kekuatan dan kekakuan yang berpengaruh terhadap perilaku struktur.

Berdasarkan SNI 03-2847-2002 dinding bata hanya difungsikan sebagai komponen non struktural yaitu tidak diperhitungkan sebagai penerima beban melainkan dalam perencanaan struktur bangunan sipil konstruksi dinding bata hanya diperlakukan sebagai beban.Sedangkan interaksi dinding bata dengan portal yang mengelilinginya seringkali diabaikan.

Penelitian ini bertujuan untuk mengevaluasi seberapa besar kapasitas, kekakuan dan daktilitas struktur portal sederhana dengan pasangan dinding bata, serta mengevaluasi pola keruntuhan yang terjadi akibat beban geser.

\section{TINJAUAN PUSTAKA}

\section{$2.1 \quad$ Umum}

Dinding merupakan salah satu elemen dari bangunan yang biasa digunakan sebagai partisi atau penutup luar pada struktur portal beton bertulang khususnya untuk bangunan rendah dan bertingkat sedang. Pemasangannya menunggu sampai struktur utama (portal beton bertulang) selesai dikerjakan, sehingga dalam perencanaannya dianggap sebagai komponen non-struktur yakni dianggap sebagai beban bukan pemikul beban.

Meskipun dikategorikan sebagai komponen non-struktur tetapi dinding mempunyai kecenderungan berinteraksi dengan portal yang ditempatinya, terutama bila ada beban lateral yang besar seperti beban gempa. Dinding pengisi memberi sumbangan yang besar terhadap kekakuan dan kekuatan struktur, sehingga perilaku keruntuhannya berbeda dibanding portal terbuka.

\subsection{Dinding Bata}

Perilaku dinding bata merupakan kombinasi dari tiga macam perilaku, yaitu perilaku portal beton bertulang, perilaku dinding bata, dan perilaku interaksi antara dinding bata dengan portal beton bertulang, sebagaimana tampak pada Gambar 1. (Tu dkk. 2006)

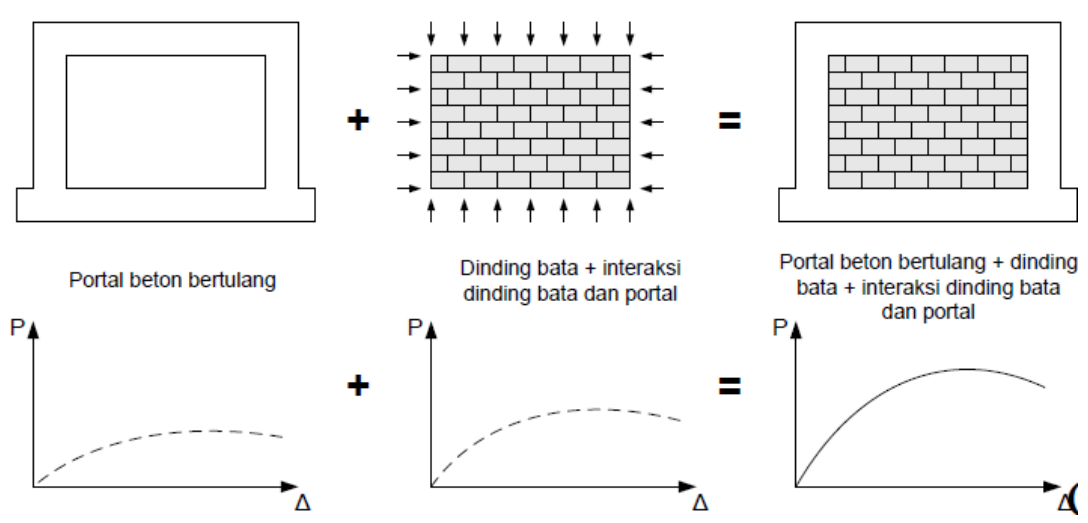

Gambar 1.Perilaku Dinding Bata Pada Portal Beton Bertulang (Tu dkk. 2006)

Kekuatan lateral dinding pasangan bata merah sangat tergantung pada pola keruntuhan yang terjadi.Ada dua jenis kegagalan pada dinding bata yang berkaitan dengan arah gaya yang bekerja: 
a) Out-plane failure diakibatkan oleh gaya yang bekerja tegak lurus pada bidang dinding. Dinding bata akan mengalami keruntuhan menyeluruh karena memiliki kemampuan sangat kecil untuk menahan gaya out-plane.

b) In-plane failure diakibatkan oleh gaya yang bekerja sejajar pada bidang dinding.

Ada beberapa tipe kegagalan pada dinding bata akibat gaya lateral (in-planeload), seperti:

1. Tension Failure Mode: Kegagalan tarik dari kolom yang tidak kuat menahan tarik akibat momen

2. Sliding shear failure: Kegagalan geser pada dinding sepanjang arah horisontal dekat atau tepat pada setengah ketinggian panel dinding pengisi

3. Diagonal Tensile Cracking: Retak sepanjang diagonal dinding bata karena tarik

4. Compession failure of the diagonal strut

5. Flexural or shear failure of the columns

\section{MODEL PENELITIAN}

\subsection{Benda Uji}

Penelitian ini berdasarkan dari gedung tinggi 5 lantai dengan dimensi kolom 75 x $75 \mathrm{~cm}$, jarak antar kolom 4 meter dan tinggi antar lantai $3 \mathrm{~m}$. Untuk benda uji dengan pemodelan portal sederhana 1 lantai. Sloof dan balok dibuat kaku dengan tidak mengharapkan perlemahan pada daerah tersebut, karena yang ditinjau hanya bagian kolom. Ukuran dalam model penelitian dipakai dengan skala 1:5 dimana dimensi kolom 15 x $15 \mathrm{~cm}$, jarak antar kolom $80 \mathrm{~cm}$ dan tinggi $60 \mathrm{~cm}$. Penulangan pada kolom berdasarkan rasio tulangan $1,4 \%$.

Bata yang digunakan dalam penelitian adalah bata normal dan bata skala. Untuk bata normal adalah bata yang ada di pasaran dengan ukuran $18 \times 9 \times 5 \mathrm{~cm}$, sedangkan bata skala dengan ukuran $9 \times 4,5 \times 2,5 \mathrm{~cm}$. Penelitian dilakukan dengan lima jenis benda uji yaitu struktur portal tanpa dinding bata, struktur portal dengan dinding bata tanpa plesteran, struktur portal dengan dinding bata skala tanpa plesteran, struktur portal dengan dinding bata dengan plesteran, dan struktur portal dengan dinding bata skala dengan plesteran. Model penelitian ini diperlihatkan dalam gambar 2 dan 3.

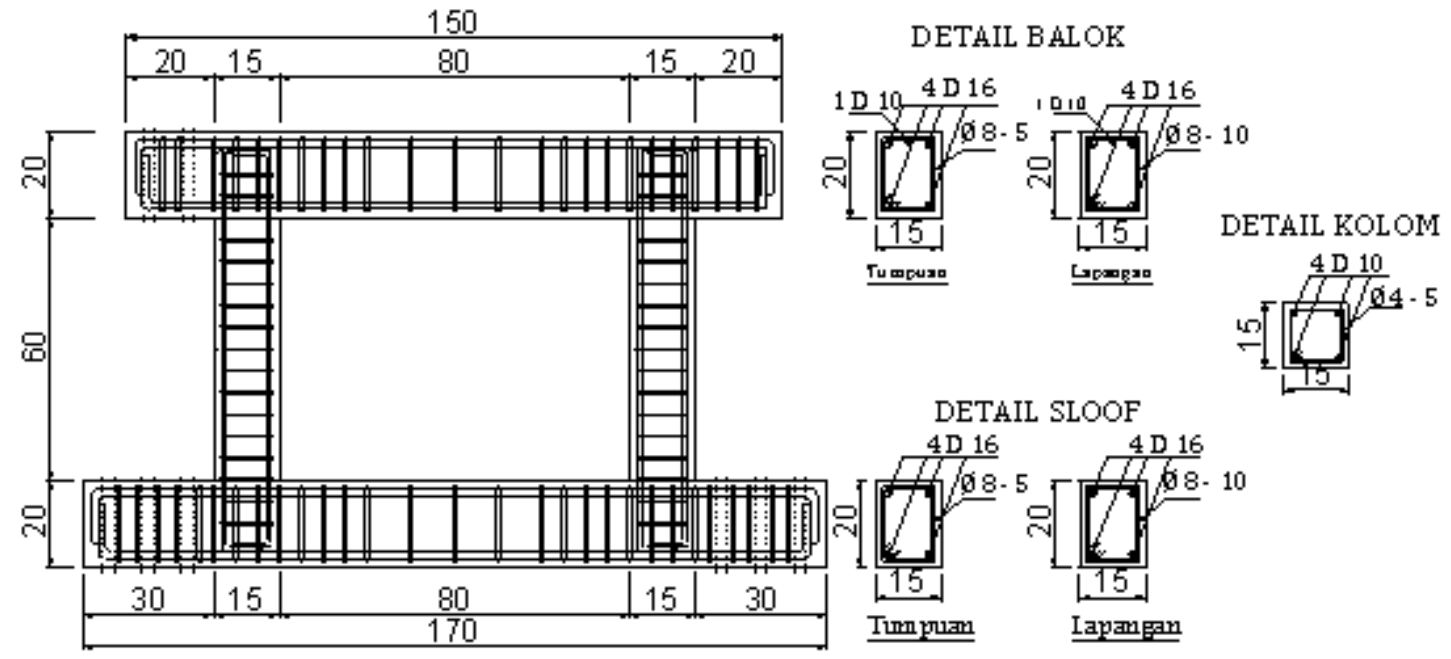

Gambar 2.Portal dan Detail Beton Bertulang 


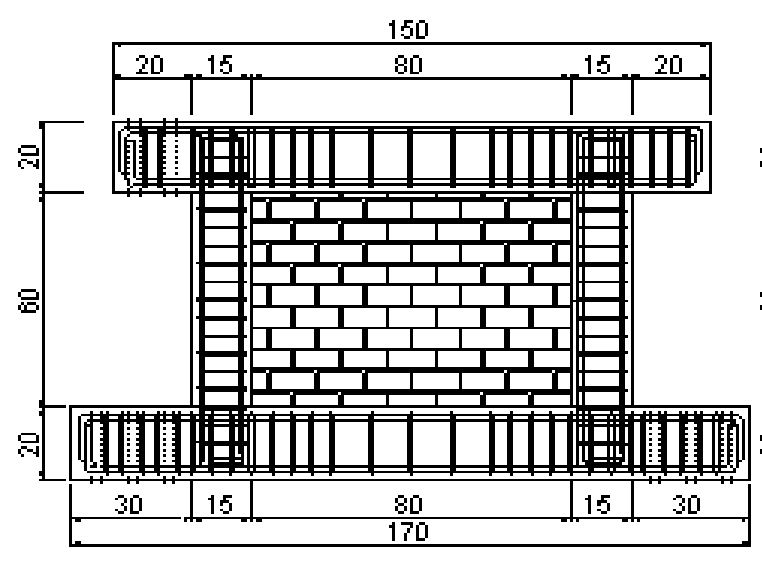

BÁTÁ BIÁSÁ

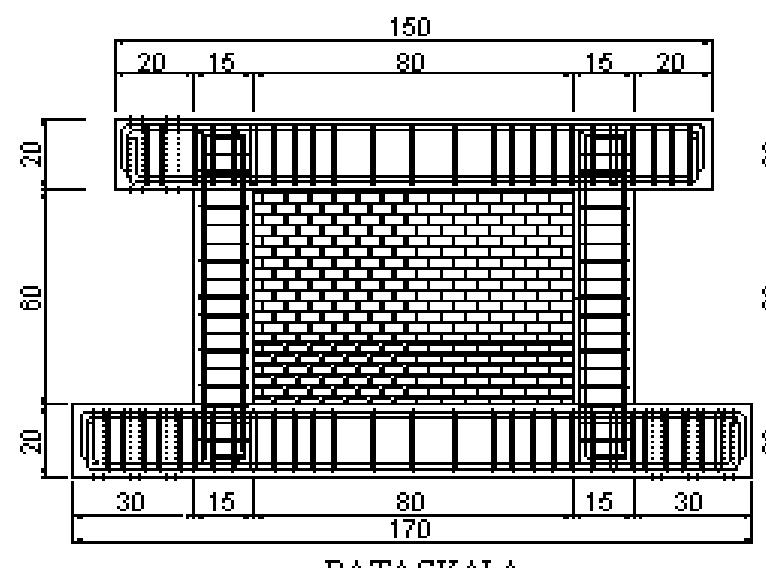

BA TA SKALA

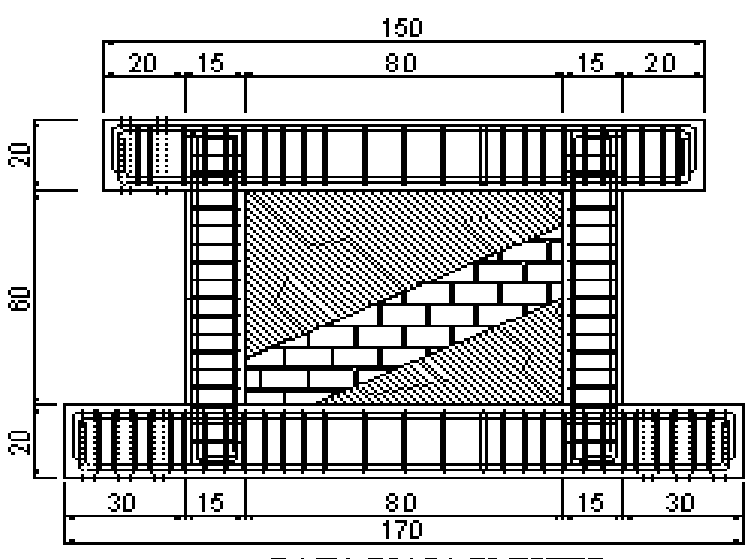

BATA BIASSA FLESTER

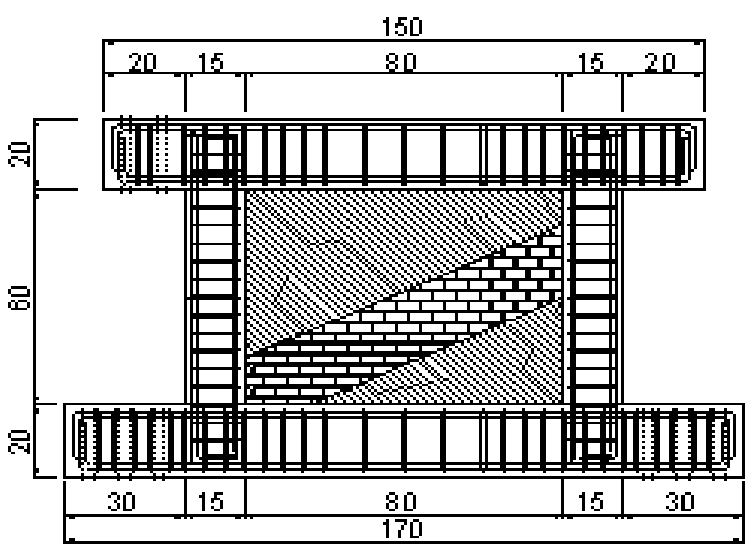

BA TA SKALA PLESTER

Gambar 3.Portal Dengan Pasangan Dindingl

Tabel 1. Tabel Idensifikasi Specimen

\begin{tabular}{|c|c|l|}
\hline No & $\begin{array}{c}\text { Kode } \\
\text { Specimen }\end{array}$ & \multicolumn{1}{|c|}{ Jenis Benda Uji } \\
\hline 1 & PT & Portal \\
\hline 2 & D1 & Portal Pasang Diding Bata Ukuran Normal \\
\hline 3 & D2 & Portal Pasang Diding Bata Di Plester Ukuran Normal \\
\hline 4 & D3 & Portal Pasang Diding Bata Ukuran Skala \\
\hline 5 & D4 & Portal Pasang Diding Bata Di Plester Ukuran Skala \\
\hline
\end{tabular}

\subsection{Persiapan Pengujian( Eksperimental Set Up)}

Pada saat penyetingan dan pemasangan benda uji pada frame uji, sloof pada benda uji dipasang terikat pada frame dan dibaut dengan baut berdiameter $25,4 \mathrm{~mm}$ (1 in) sehingga benda uji dapat diasumsikan sebagai terjepit sempurna. Kemudian pasang dan rangkai peralatan yang digunakan pada frame uji dan benda uji sebagai berikut:

1. Pasang besi plat untuk perletakan Load Cell di bagian sebelah kiri balok dan kemudian pasang load cell.Load Cell adalah alat untuk penerima beban untuk disalurkan pada portal.

2. Kemudian pasangactuator pada kedudukan plat yang telah di siapkan pada frame uji sebelah kiri. Actuator adalah media untuk penyalur beban dari Hydraulic Jet.

3. Pasang Hydraulic Jet yang berfungsi sebagai pemompa beban dengan menyambungkan kabelnya pada Actuator.

4. Pasang LVDT pertama pada bagian atas frame uji dengan bagian ujung bacaan menyentuh balok pada portal dengan tujuan untuk membaca perpindahan secara vertikal dan lanjutkan 
pasang LVDT ke dua pada tiang Frame uji dengan ujung LVDT menyentuh balok dengan tujuan untuk mengukur besar perpintahan arah horizontal.

Untuk mengukur besarnya beban dorong yang dihasilkan oleh actuator

5. Kemudian persiapkan Data Logger yang berfungsi sebagai media untuk membaca hasil yang dikeluarkan oleh Load Cell dan LVDT.

6. Sambungkan kabel dari Load Cell dan LVDT dengan Data Logger.

Semua peralatan terpasang sesuai gambar 4.
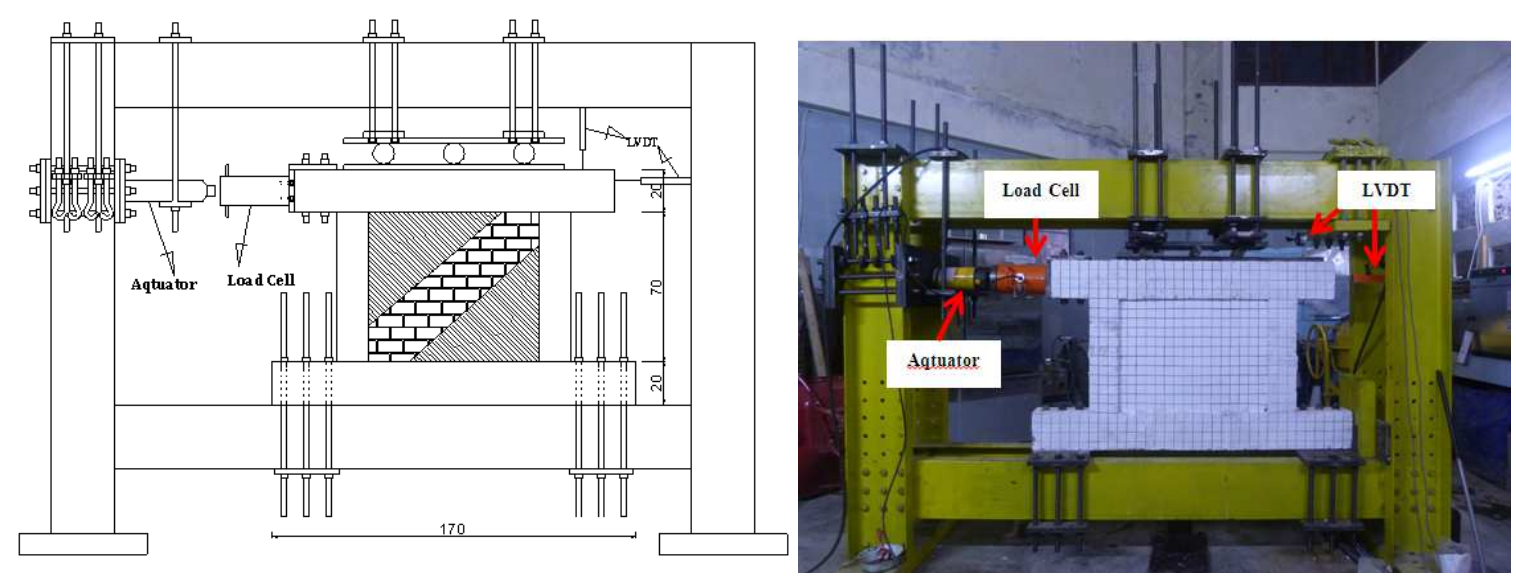

Gambar 4.Penempatan Alat Pengujian Pada Frame

\subsection{Prosedur Pengujian}

Prosedur pengujian yang dilakukan adalah:

1. Pengujian beton

Pengujian beton dilakukan untuk mengetahui berapa nilai mutu beton yang di pakai dalam pengujian dan akan di gunakan untuk penguujian secara analitik dan numeric. Kekuatan tekan beton merupakan perbandingan antara nilai kuat tekan beton dengan luas alas permukaan benda uji.

2. Pengujian kuat tarik baja tulangan

Besi tulangan yang digunakan adalah besi tulangan yang banyak dijumpai di pasaran, biasanya besi tulangan ini memiliki variasi tegangan leleh dan tegangan ultimet yang beragam.

3. Pengujian dinding bata

Pengujian dinding bata dimaksudkan untuk mengetahui kuat tekan dinding bata akibat pembebanan dan akan digunakan untuk pengujian secara numerik.

4. Pengujian benda uji

Setelah set up pengujian dilakukan maka dilanjutkan dengan pengujian benda uji. Pengujian benda uji di mulai dengan memberikan beban melalui Hydraulic Jetsecara perlahan. Beban diberikan secara bertahap sampai benda uji tersebut runtuh. Pada saat pengujian amati dan beri tanda dimana dan pada saat beban berapa retak yang terjadi. Data yang didapat dalam pengujian ini adalah besaran perpindahan yang terjadi melalui bacaan dari LVDT. Untuk besaran beban dari bacaLoad Cell. Kedua hasil di dapat dari Data Logger.

\section{HASIL DAN PEMBAHASAN}


Data yang diperoleh dari hasil pengujian berupa beban, perpindahan, dan pola retak yang dilihat secara visual.Grafik dari hasil pengujian dapat dilihat pada gambar 5 .

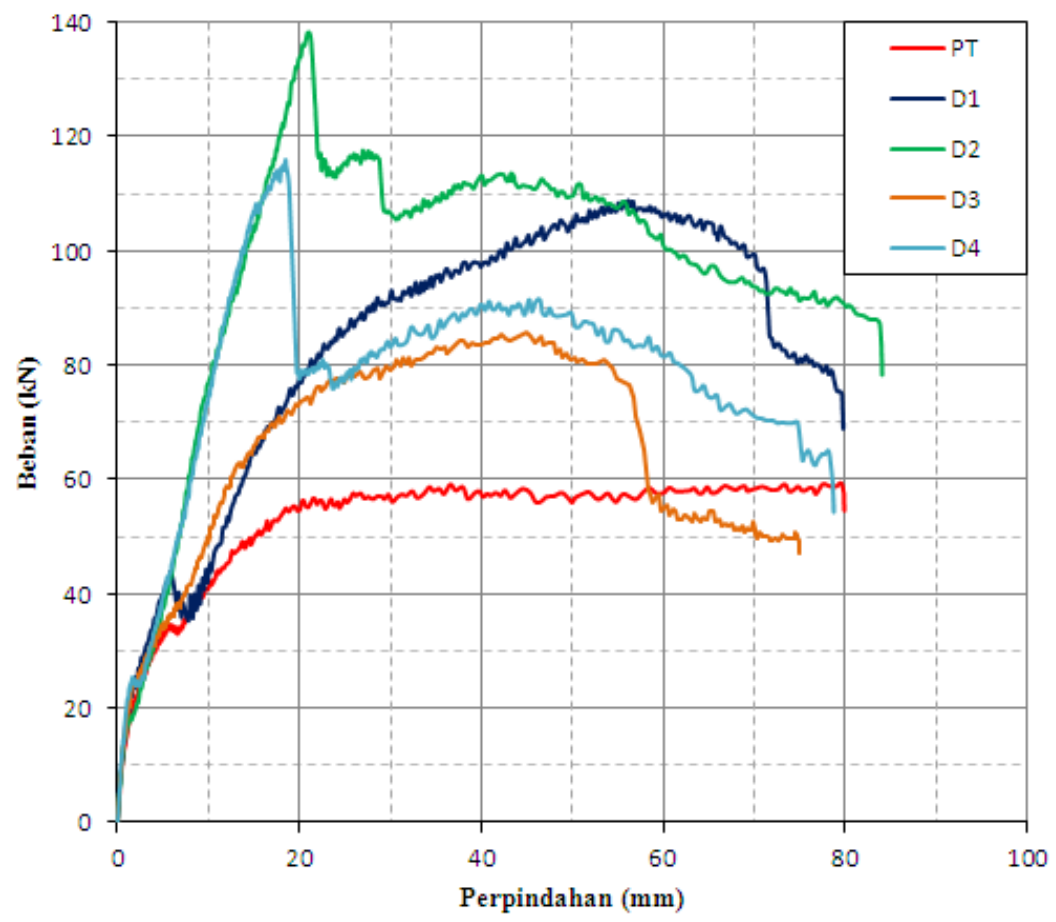

( a )

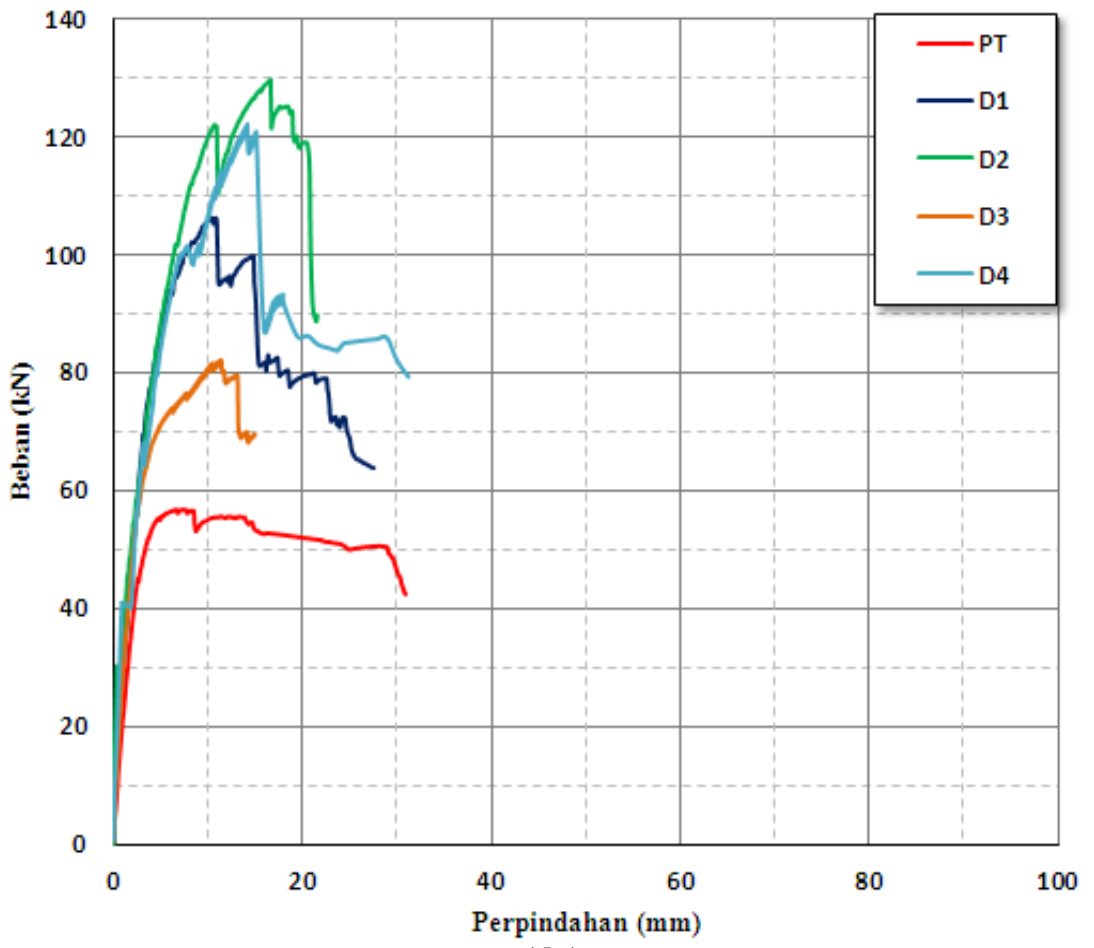

( b )

Gambar 5.Hasil Pengujian

( a ) Eksperimental

( b ) Numerik 
Untuk pengujian secara eksperimen, kapasitas yang dapat ditahan oleh struktur portal 59,4 kN. Setelah dilakukan pemasangan dinding bata, untuk bata standar kapasitas struktur bertambah 83,33\% dan bata skala 41,67\% terhadap kapasitas struktur tanpa pasang dinding bata. Untuk pasang bata standar dengan plesteran terjadi peningkatan kapasitas 132,8\% dan bata skala 91,67\% terhadap kapasitas struktur portal tanpa pasang dinding bata.

Dengan pemasangan dinding bata, kekakuan struktur bertambah. Dalam pengujian ini kekakuan didapat dari beban puncak sebelum terjadi retak di bagi perpindahan yang terjadi.

$$
\text { Kekakuan }=\frac{P}{d}
$$

Dimana: $\quad \mathrm{P}=$ beban sebelum lelah

$\mathrm{d}=$ perpindahan

Tabel 2. Nilai Kekakuan

\begin{tabular}{|l|c|c|c|c|}
\hline No & $\begin{array}{c}\text { Benda } \\
\text { Uji }\end{array}$ & $\begin{array}{c}\text { Beban } \\
(\mathrm{kN})\end{array}$ & $\begin{array}{c}\text { Displacement } \\
(\mathrm{mm})\end{array}$ & $\begin{array}{c}\text { Kekakuan } \\
(\mathrm{kN} / \mathrm{mm})\end{array}$ \\
\hline 1 & PT & 55.4 & 19.48 & 2.84 \\
\hline 2 & D1 & 94.3 & 31 & 3.04 \\
\hline 3 & D2 & 118.4 & 17.6 & 6.73 \\
\hline 4 & D3 & 20 & 2.9 & 6.89 \\
\hline 5 & D4 & 26.25 & 3.5 & 7.5 \\
\hline
\end{tabular}

Kekakuan portal dengan pasang dinding bata standar terjadi peningkatan $6.96 \%$ dan bata skala $20.87 \%$ dari portal tanpa pasang dinding. Sedangkan untuk portal dengan pasang dinding bata standar di plesteran dapat meningkatkan kekakuan $136.55 \%$ dan bata skala 31,57\% dari portal tanpa pasang dinding bata.

Daktilitas merupakan kemampuan dari suatustruktur untuk mengalami perpindahan yang besarsebelum mengalami keruntuhan Dengan pemasangan dinging bata membuat daktilitas struktur menurun.

Tabel 3. Nilai Daktilitas

\begin{tabular}{|c|c|c|c|c|}
\hline No & $\begin{array}{c}\text { Benda } \\
\text { Uji }\end{array}$ & $\begin{array}{c}\text { Displacement } \\
\text { Hancur(mm) }\end{array}$ & $\begin{array}{c}\text { Displacement } \\
\text { Leleh -1 }(\mathrm{mm})\end{array}$ & Daktilitas \\
\hline 1 & PT & 38 & 4.7 & 8.08 \\
\hline 2 & D1 & 34.18 & 71.34 & 2.09 \\
\hline 3 & D2 & 17.6 & 21.34 & 1.22 \\
\hline 4 & D3 & 32 & 5 & 6.4 \\
\hline 5 & D4 & 18 & 3.5 & 5.14 \\
\hline
\end{tabular}

Portal beton bertulang dengan pasangan dinding mempunyai daktilitas lebih kecil dari portal tanpa pasangan dinding dalam menerima beban horizontal. Daktilitas bata standar terjadi penurunan $70,31 \%$, sedangkan untuk bata skala terjadi penurunan $63,61 \%$. Penurunan daktilitas pada portal dipengaruhi oleh runtuhnya dinding yang mengakibatkan terjadinya penurunan kapasitas secara signifikan.

Untuk pengujian secara numerik, dengan pemasangan dinding bata kapasitas struktur bertambah75,03 \% untuk bata standar, dan 32,20\% untuk bata skala terhadap kapasitas struktur tanpa pasang dinding bata. Untuk pasang bata di plester terjadi peningkatan kapasitas struktur menjadi $133 \%$ untuk bata standar dan $96,71 \%$ untuk bata skala terhadap kapasitas struktur tanpa pasang dinding bata. 
Kekakuan struktur beton bertulang dengan dinding pasang bata lebih tinggi dari pada tanpa pasang bata. Kekakuan pada portal dengan dinding bata tanpa plester bertambah $66.63 \%$ dari kekakuan portal tanpa dinding, sedangkan portal dengan dinding diplester kekakuannya bertambah $91.35 \%$.
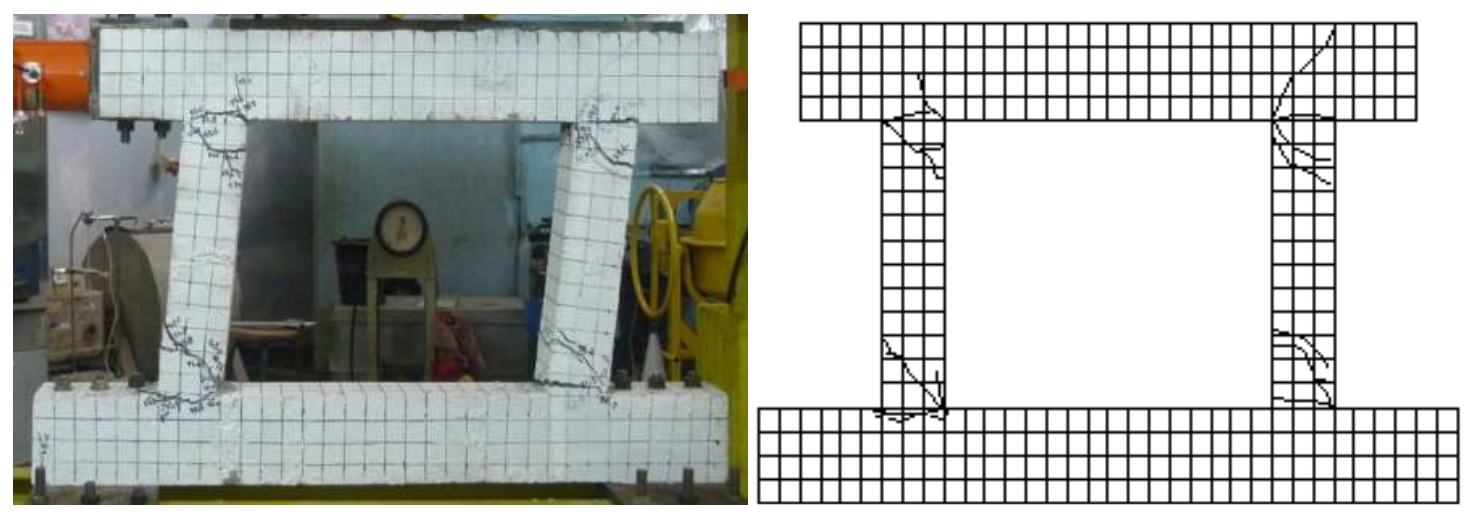

Gambar 6.Pola Retak Beton Bertulang Tanpa Dinding
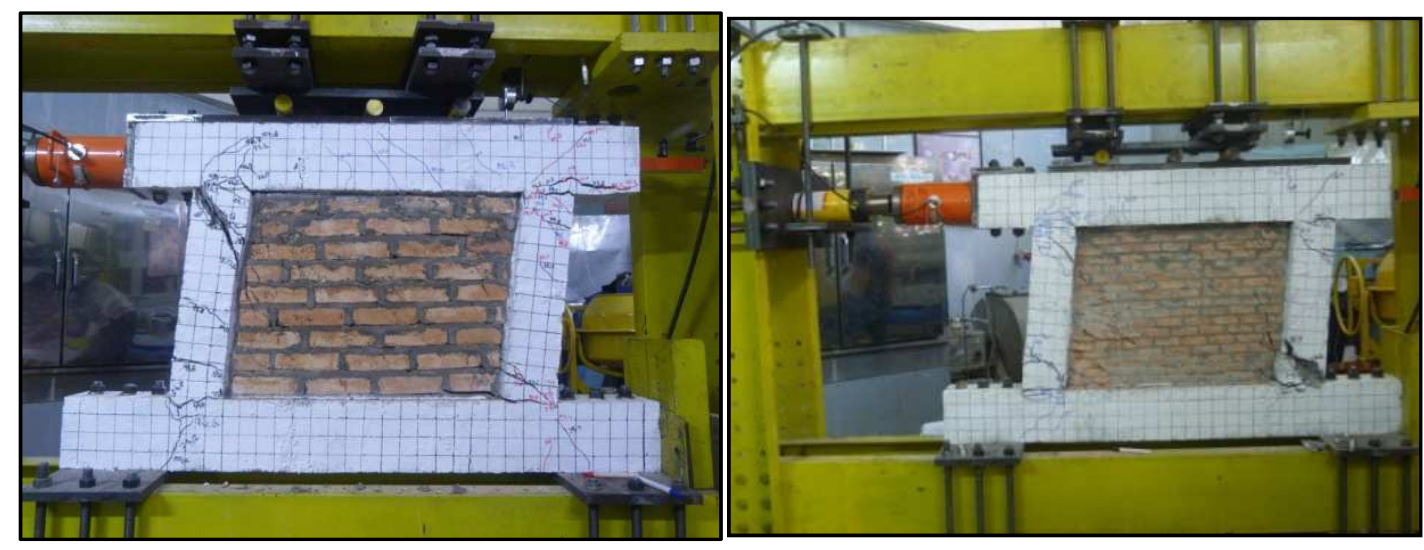

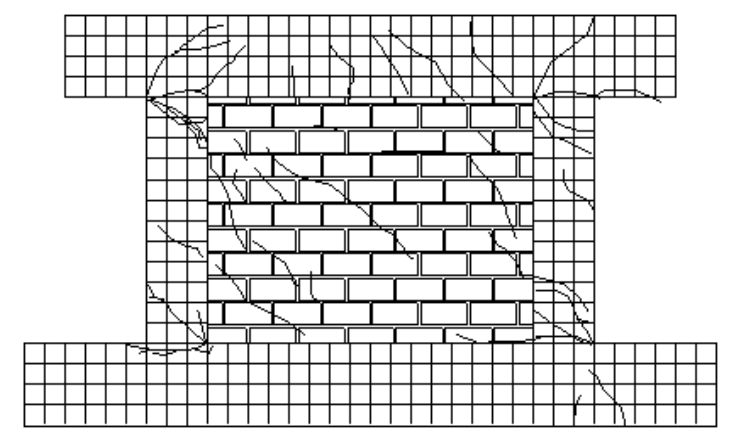

BATA STANDAR

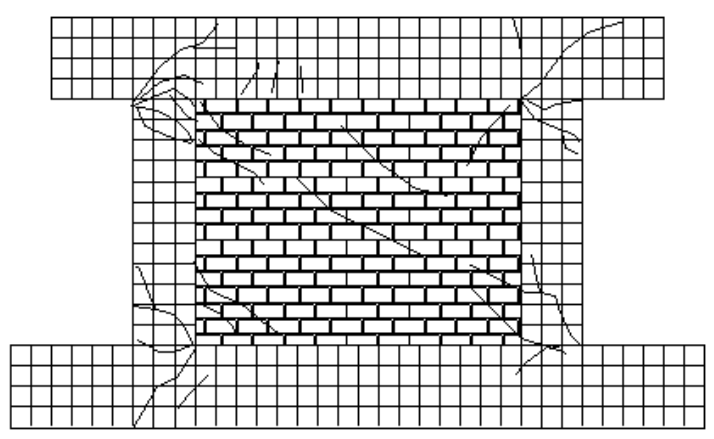

BATA SKALA

Gambar 7.Pola Retak Beton Bertulang Dengan Dinding Tanpa Plesteran 


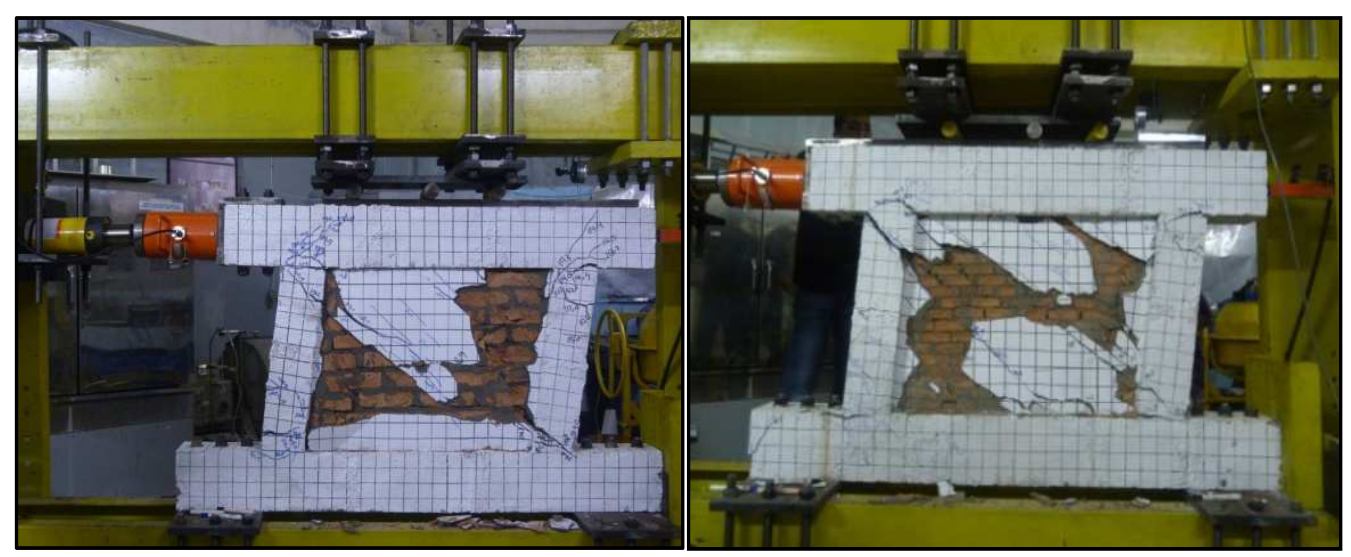

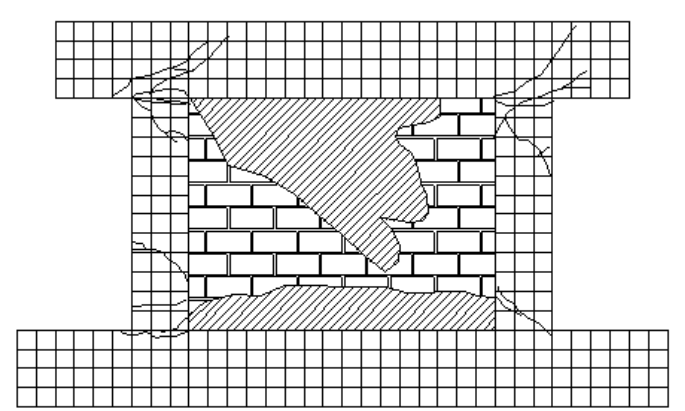

BATA STANDAR

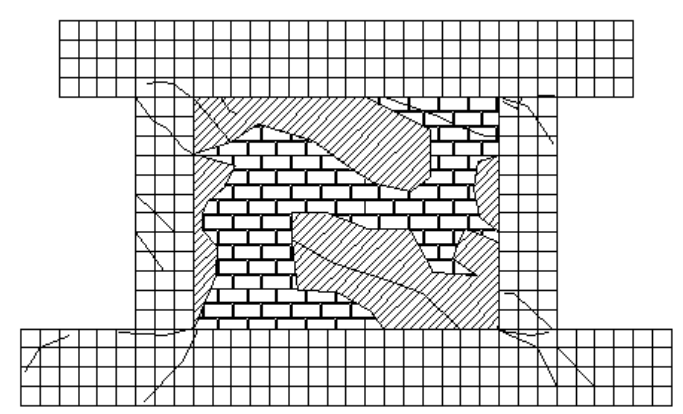

BATA SKALA

Gambar 8.Pola Retak Beton Bertulang Dengan Dinding Di Plesteran

Gambar 6. Memperlihatkan saat struktur menerima beban arah horizontal, pada kolom kiri bagian bawah mengalami tarik dan bagian atas mengalami tekan sedangkan kolom kanan atas mengalami tarik dan bagian bawah mengalami tekan. Retak pertama terjadi pada setiap ujung - ujung kolom.Retak terjadi secara diagonal. Hal ini menandakan gaya geser yang terjadi pada struktur besar. Retak yang terjadi pada ujung-ujung kolom semakin membesar sampai struktur tidak mampu menahan beban dan mengalami kehancuran.Tipe keruntuhan struktur adalah keruntuhan geser.

Gambar 7 memperlihatkan portal dengan pasang dinding tanpa plesteran retak pertama pada struktur terjadi pada kolom sebelah kiri bagian atas. Retak tersebut adalah retak diagonal yang menandakan beban geser yang bekerja besar. Tipe keruntuhan struktur adalah keruntuhan geser. Sedangkan retak yang terjadi pada dinding bata adalah retak diagonal dengan keruntuhan geser dan tipe keruntuhan berdasarkan gaya yang bekerja adalah keruntuhan In-plane failure.

Portal pasang dinding dengan plesteran retak pertama terjadi pada dinding dengan retak diagonal. Hal ini mununjukkan adanya kekuatan plesteran dalam menahan ikatan bata dalam menahan beban, sehingga kekuatan bata menjadi meningkat seperti di perlihatkan pada Gambar 8. Setelah retak pada dinding banyak, kemudian penjalaran retak terjadi ke setiap ujung - ujung kolom. Retak yang terjadi pada sturktur adalah retak diagonal dengan tipe keruntuhan geser. Sedangkan retak yang terjadi pada dinding bata adalah retak diagonal dengan keruntuhan geser dan tipe keruntuhan berdasarkan gaya yang bekerja adalah keruntuhan In-plane failure. 


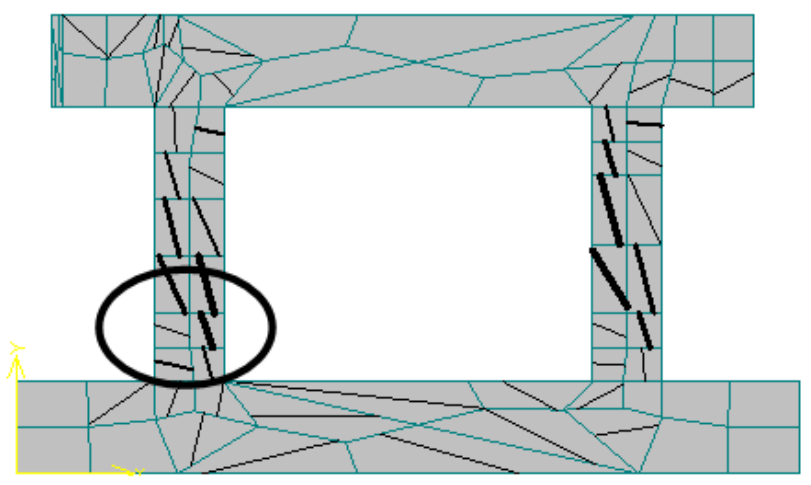

Gambar 10.Pola Retak Beton Bertulang Tanpa Dinding

Pada saaat beban maksimum, tegangan utama (prinsipal Stress) yang terjadi pada tulangan longitudinal kolom bawah yang dilingkar pada Gambar 10, mengalami tarik sebesar sebesar 319.2 MPa dan sengkang pada bagian yang sama sebesar 217.7 MPa. Jika dibandingan dengan tegangan leleh tulangan longitudinal sebesar 349.034 MPa maka saat pembebanan maksimum, tulangan longitudinal belum leleh dan sengkang telah leleh. Tulangan longitudinal leleh pada saat beban $55.43 \mathrm{kN}$ dan perpindahan sudah $10.99 \mathrm{~mm}$.

Untuk portal dengan pasang dinding bata tanpa plester, retak pertama terjadi pada dinding.Setelah semua bata retak, penjalaran retak dilanjutkan ke bagian ujung setiap kolom. Setalah beban maksimum terjadi penurunan beban secara signifikan.Penurunan beban tersebut diakibatkan oleh hilangnya pengaruh kekuatan bata dalam menerima beban geser dan selanjutnya beban ditahan oleh portal.

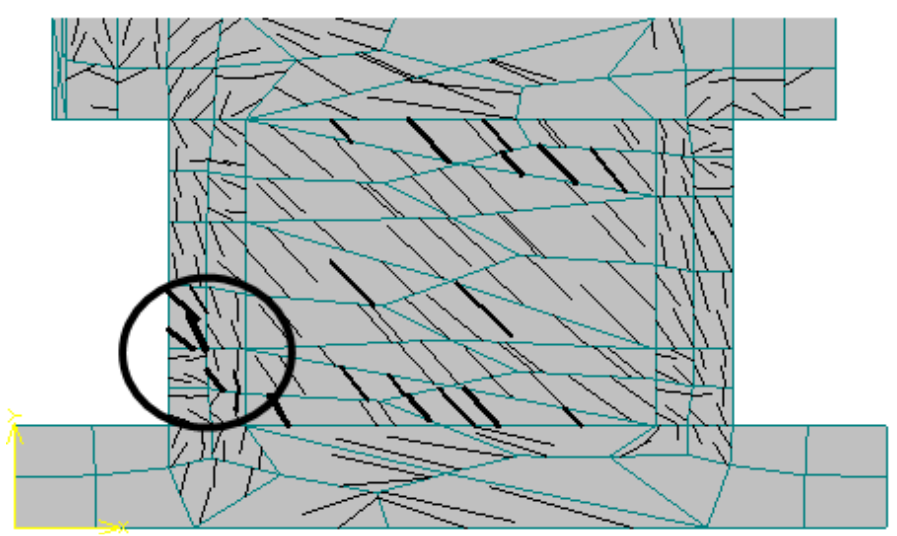

Gambar 11.Pola Retak Beton Bertulang Dengan Dinding Tanpa Plesteran

Untuk portal dengan pasang dinding bata tanpa plester, pada saat beban maksimum tegangan utama (prinsipal Stress) yang terjadi pada tulangan longitudinal kolom bawah yang dilingkar pada Gambar 11, mengalami tarik sebesar sebesar 341.9 MPa dengan perpindahan $10.84 \mathrm{~mm}$ dan sengkang pada bagian yang sama sebesar $226 \mathrm{MPa}$. Jika dibandingan dengan tegangan leleh tulangan longitudinal sebesar $349.034 \mathrm{MPa}$ maka saat pembebanan maksimum, tulangan longitudinal belum leleh. Tulangan longitudinal lelah pada saat pembeban $95.05 \mathrm{kN}$ dengan perpindahan yang terjadi $11.31 \mathrm{~mm}$.

Untuk portal dengan pasang dinding bata diplester, beban maksimum tegangan utama (prinsipal Stress) yang terjadi pada tulangan longitudinal kolom bawah mengalami tarik sebesar sebesar 381.3 MPa dan sengkang pada bagian yang sama sebesar $249 \mathrm{MPa}$. Jika dibandingan dengan 
tegangan leleh tulangan longitudinal sebesar 349.034 MPa maka saat pembebanan maksimum, tulangan longitudinal sudah leleh. Leleh pertama terjadi pada pembeban $118.9 \mathrm{kN}$ dengan perpindahan $12.32 \mathrm{~mm}$.

\section{KESIMPULAN}

Berdasarkan penelitian yang telah dilakukan dapat ditarik kesimpulan berupa:

1. Dinding bata tidak berfungsi sebagai beban melainkan berfungsi sebagai penerima beban saat terjadi pembebanan geser, ini dibuktikan dari hasil pengujian terjadinya peningkatan kapasitas beban yang disumbangankandinding bata tanpa diplester $85.28 \%$ untuk bata normal, $41,67 \%$ untuk bata skala dan sumbangan bata di plester $132.16 \%$ untuk bata normal, $91,67 \%$ untuk bata skala terhadap struktur beton bertulang.

2. Dinding bata dapat meningkatkan kekakuan struktur, ini dibuktikan dengan pemasangan dinding bata menaikan kekakuan struktur $6.96 \%$ untuk bata normal dan 20,87 \% untuk bata skala. Pemasangan dinding bata diplester dapat meningkatkan kekakuan struktur $136.55 \%$ untuk bata normal dan 31,57 \% untuk bata skala.

3. Dengan pemasang dinding bata, daktilitas struktur berkurang, ini dibuktikan dengan berkurangnya daktilitas struktur dengan pasang dinding bata sebesar $36.98 \%$ dan pasang dinding bata diplester $57.36 \%$ terhadap portal struktur beton bertulang.

4. Keruntuhan dinding bata adalah keruntuhan geser yang ditandai dengan terjadinya retak diagonal pada dinding. Berdasarkan arah gaya yang bekerja, terjadi keruntuhan In-plane failure.

\section{DAFTAR KEPUSTAKAAN}

Akinar Reka (2002), Model Inelastik Dinding Bata Sebagai Elasto Britle Struktur Diagonal Pada Analisis Portal Beton 3D Akibat Gempa, Depok

Bukheri Cecep (2013),Pengaruh Penambahan Baja Tulangan Horizontal Pada Dinding Pemasangan Bata Merah Horizontal. Jurnal Permukiman Vol. 8 No. 1 April 2013 : 1-12

Cervenka V, Jendele L, dan Cervenka J. 2012, Atena Theory. Cervenka Consulting Ltd.

Chu-Kia, Wang, (1999), Desain Beton Bertulang, Erlangga, Jakarta

Dipohusodo, I., (1994), Structure beton bertulang, PT. Gramedia Pustaka Utama, Jakarta

Leksono s Redha (2014), Studi Pengaruh Kekuatan dan Kekakuan Dinding Bata Pada Bangunan Bertingkat. ITS-Paper 28414

Maidiawati, and Yasushi, Sanada. 2008. Investigation and Analysis of Building Damaged during the September 2007 Sumatera Indonesia Earthquakes. Journal of Asian Architecture and Building Engineering. Vol. 7 No. 2. 371-378.

Standar Nasional Indonesia 03-2847, (2002), Tata cara perencanaan struktur beton untuk bangunan gedung.

Tu, Y.H., Hwang, S.J., and Chiou, T.C. (2006), "In-Site Pushover Tests and Seismic Assessment on School Buildings in Taiwan", Proceeding of 4th International Conference on Earthquake Engineering, No. 147, Taipei. 